\title{
Mycelial growth, pathogenicity, aggressiveness and apothecial development of Sclerotinia sclerotiorum isolates from Brazil and the United States in contrasting temperature regimes
}

\author{
Claudia Vieira Godoy ${ }^{1}$, Lucimara Junko Koga ${ }^{2}$, Maria Cristina Neves de Oliveira ${ }^{1}$, Curtis B. Hill ${ }^{3}$, Glen Lee Hartman ${ }^{2,4}$
}

${ }^{1}$ Embrapa Soja, Rodovia João Carlos Strass, CEP 86001-970 Londrina, PR, Brasil; ${ }^{2}$ Department of Crop Sciences, University of Illinois, 1101 Peabody Drive, 61801 Urbana, IL, USA; ${ }^{3}$ Agricen Sciences, LLC, Pilot Point, TX, USA; ${ }^{4}$ USDA Agricultural Research Service, Urbana, IL, USA Autor para correspondência: Cláudia Vieira Godoy (claudia.godoy@embrapa.br)

Data de chegada: 06/05/2016. Aceito para publicação em: 13/07/2017.

$10.1590 / 0100-5405 / 2188$

\section{ABSTRACT}

Godoy, C.V.; Koga, L.J.; Oliveira, M.C.N.; Hill, C.B.; Hartman, G.L. Mycelial growth, pathogenicity, aggressiveness and apothecial development of Sclerotinia sclerotiorum isolates from Brazil and the United States in contrasting temperature regimes. Summa Phytopathologica, v.43, n.4, p.263-268, 2017.

Fungi can adapt to environmental conditions and produce different physiological responses. The aim of this study was to verify the existence of Sclerotinia sclerotiorum temperature ecotypes in isolates from Brazil and the USA. Ten S. sclerotiorum isolates from tropical and subtropical regions of Brazil and six isolates from the USA were used to measure mycelial growth, pathogenicity and aggressiveness on bean, canola and soybean, as well as apothecial formation at contrasting temperatures. For mycelial growth, regardless of the origin, all isolates grew faster at $20^{\circ} \mathrm{C}$, compared to $27^{\circ} \mathrm{C}$. For pathogenicity and aggressiveness, disease severity was greater at $20^{\circ} \mathrm{C}$ than at $30^{\circ} \mathrm{C}$ considering all isolates. As regards apothecial production, only Brazilian isolates were capable of producing apothecia with no preconditioning. After preconditioning at $4^{\circ} \mathrm{C}$ during 40 days, isolates from Brazil and the USA produced apothecia. None of the 16 isolates was capable of producing apothecia at $30^{\circ} \mathrm{C}$ after 40 days. Results indicated no adaptation of $S$. sclerotiorum isolates from Brazil to grow or colonize leaflets at higher temperatures, compared to isolates from the USA. Only sclerotia from S. sclerotiorum isolates from Brazil were capable of germinating carpogenically without preconditioning.

Keywords: carpogenic germination, white mold, temperature, ecotypes

\section{RESUMO}

Godoy, C.V.; Koga, L.J.; Oliveira, M.C.N.; Hill, C.B.; Hartman, G.L. Crescimento micelial, patogenicidade, agressividade e desenvolvimento de apotécios de isolados de Sclerotinia sclerotiorum do Brasil e dos Estados Unidos em regimes de temperatura contrastantes. Summa Phytopathologica, v.43, n.4, p.263-268, 2017.

Os fungos podem se adaptar a condições ambientais e produzir diferentes respostas fisiológicas. O objetivo deste estudo foi verificar a existência de ecótipos de temperatura para Sclerotinia sclerotiorum em isolados do Brasil e dos EUA. Dez isolados de $S$. sclerotiorum de regiões tropicais e subtropicais do Brasil e seis dos EUA foram avaliados para crescimento micelial, patogenicidade, agressividade em feijão, canola e soja e formação de apotécio em temperaturas contrastantes. Para o crescimento micelial, independente da origem do isolado, todos cresceram mais rápido a $20^{\circ} \mathrm{C}$ em comparação com $27^{\circ} \mathrm{C}$. Para patogenicidade e agressividade, a severidade da doença foi maior a $20^{\circ} \mathrm{C}$ do que a $30^{\circ} \mathrm{C}$, para todos isolados. Para produção de apotécio, somente isolados do Brasil foram capazes de produzir apotécio sem pré-condicionamento. Com pré-condicionamento a $4^{\circ} \mathrm{C}$ por 40 dias, os isolados do Brasil e dos EUA produziram apotécio. Nenhum dos 16 isolados foi capaz de produzir apotécio a $30^{\circ} \mathrm{C}$, após 40 dias. Os resultados não mostraram uma adaptação de isolados de S. sclerotiorum do Brasil para crescer ou colonizar folíolos em temperaturas mais altas, em comparação com os isolados dos EUA. Apenas escleródios de isolados de S. sclerotiorum do Brasil foram capazes de germinar carpogenicamente sem pré-condicionamento.

Palavras-chave: germinação carpogênica, mofo-branco, temperatura, ecótipo

The fungus Sclerotinia sclerotiorum (Lib.) de Bary is an important pathogen which is distributed worldwide and attacks over 600 plant species, including important crops such as sunflower, soybean, oilseed rape, dry bean, peanut, lentil, various vegetables and numerous weeds $(3,7,18)$. This fungus produces sclerotia as survival structures that can germinate either carpogenically, to form apothecia which in turn release ascospores for infection, or myceliogenically, to directly infect host plants (20). For most diseases caused by S. sclerotiorum, ascospores produced through carpogenic germination are the primary source of epidemics (1).
Development of diseases caused by S. sclerotiorum is strongly dependent on environmental factors. High soil moisture is required for apothecial development, while dry periods can prevent carpogenic germination $(1,23)$. Favorable temperature for apothecial development of $S$. sclerotiorum varies between $10^{\circ} \mathrm{C}$ and $20^{\circ} \mathrm{C}$, although variation in the optimum temperature requirements has been reported $(4,5,9,10$, $11,21)$. Light intensity influences the time for apothecial formation and the optimum temperature range for germination (21). Sclerotia of $S$ sclerotiorum were reported to require a preconditioning period under wet and low temperature conditions $(15,16,21)$ but also germinate 
without preconditioning $(9,10,11,19)$.

Genetic variations between $S$. sclerotiorum populations and aggressiveness among isolates have been established $(6,17)$. Reports have suggested the existence of $S$. sclerotiorum temperature ecotypes $(9,10,21)$. Ecotypes are sub-groups of the pathogen which have different capacities to perform in different environments (22). This could be important to explain why diseases caused by this pathogen can affect susceptible host crops in certain geographic areas. For instance, S. sclerotiorum does not produce significant disease on soybean or peanut grown during the summer in the south of the USA but has been found to attack canola grown during the winter in that same geographic region (4). In contrast, soybean grown in parts of South America, where temperatures are comparable to those in the summer in southern USA, has been attacked by $S$. sclerotiorum in regions of high altitude and low night temperature (8). This could be attributed to different ecotypes present in South America, compared to those in the USA, which have different capacity to perform at higher temperatures.

The aim of this study was to determine whether S. sclerotiorum ecotypes exist among isolates collected from Brazil and the USA, based on their differential capacity to grow, colonize plants and develop apothecia at different temperatures.

\section{MATERIAL AND METHODS}

Ten $S$. sclerotiorum isolates from Brazil (APHIS permit \#P52611-02826) and six isolates from the USA, maintained at the National Soybean Research Center of the University of Illinois, were used in the experiments (Table 1). Brazilian isolates were collected from subtropical (BR1 and BR9) and tropical regions (BR2 - BR8, and BR10) from sunflower (BR1) and soybean plants (BR2 - BR10) (Table 1). Isolates from the USA were sampled from soybean plants from the upper Midwest producing region (US1 - US4) and from bell pepper (US5) and eggplant (US6) from the southern region of the country. Bulk collections of sclerotia were stored at $4^{\circ} \mathrm{C}$. From each collection, a single sclerotium was immersed sequentially in $4 \%$ sodium hypochlorite (4 min) and $70 \%$ ethanol ( $2 \mathrm{~min}$ ), rinsed twice in sterile distilled water and plated on potato-dextrose-agar (PDA) medium. Plates were incubated in a tissue chamber set to $12 / 12 \mathrm{~h}$ light/dark, $23^{\circ} \mathrm{C}$, for 5 days. Isolates were transferred to water-agar medium for three days of incubation at $23^{\circ} \mathrm{C}$, and hyphal tip cultures were produced by cutting hyphal tips from the outer edge of the colony; these tip cultures were then transferred to another PDA plate. Purified cultures were kept on PDA at $4{ }^{\circ} \mathrm{C}$. Prior to each experiment, inoculations were done by transferring fresh colonies from the storage cultures to new PDA plates for 72 hours, $12 / 12 \mathrm{~h}$ light/dark photoperiods, $20^{\circ} \mathrm{C} \pm 2{ }^{\circ} \mathrm{C}$.

\section{Mycelial growth}

One $6 \mathrm{~mm}$-diameter cork-borer mycelial plug of each isolate was seeded on PDA Petri plates $(9 \mathrm{~cm}$ diameter). All isolates were incubated at $20^{\circ} \mathrm{C}$ and $27^{\circ} \mathrm{C}$ under $12 / 12 \mathrm{~h}$ dark/light conditions. Colonies had their longest diameters measured as centimeters every $12 \mathrm{~h}$ until the plates were completely filled. The 36-hour measurement was used to compare the mycelial growth of isolates. The experiment was arranged in a factorial design with four replicates and was performed twice.

Pathogenicity and aggressiveness on bean, soybean and canola

S. sclerotiorum isolates (Table 1) were used to verify pathogenicity and aggressiveness at $20^{\circ} \mathrm{C}$ and $30^{\circ} \mathrm{C}$, using the detached-leaf methodology. Seeds of bean (commercial kidneybean), soybean (cultivar Resnick) and canola (cultivar Sumner) were sown in standard 1020 bedding plant cell inserts with 18 holes in soil-less planting mix and fertilized with slow-release pellets (Osmocote 13-13-13). From sowing to 2 3 weeks, trays were kept in a greenhouse at average temperature of $27^{\circ} \mathrm{C}$ and $600 \mathrm{Wm}^{2}$ supplemental illumination. Leaflets from each crop were collected and placed in Petri plates $(9 \mathrm{~cm}$ diameter) containing one filter paper layer on the bottom which was saturated with water. The leaflets of the three crops were inoculated with one $6 \mathrm{~mm}$-diameter cork-

Table 1. Origin of Sclerotinia sclerotiorum isolates.

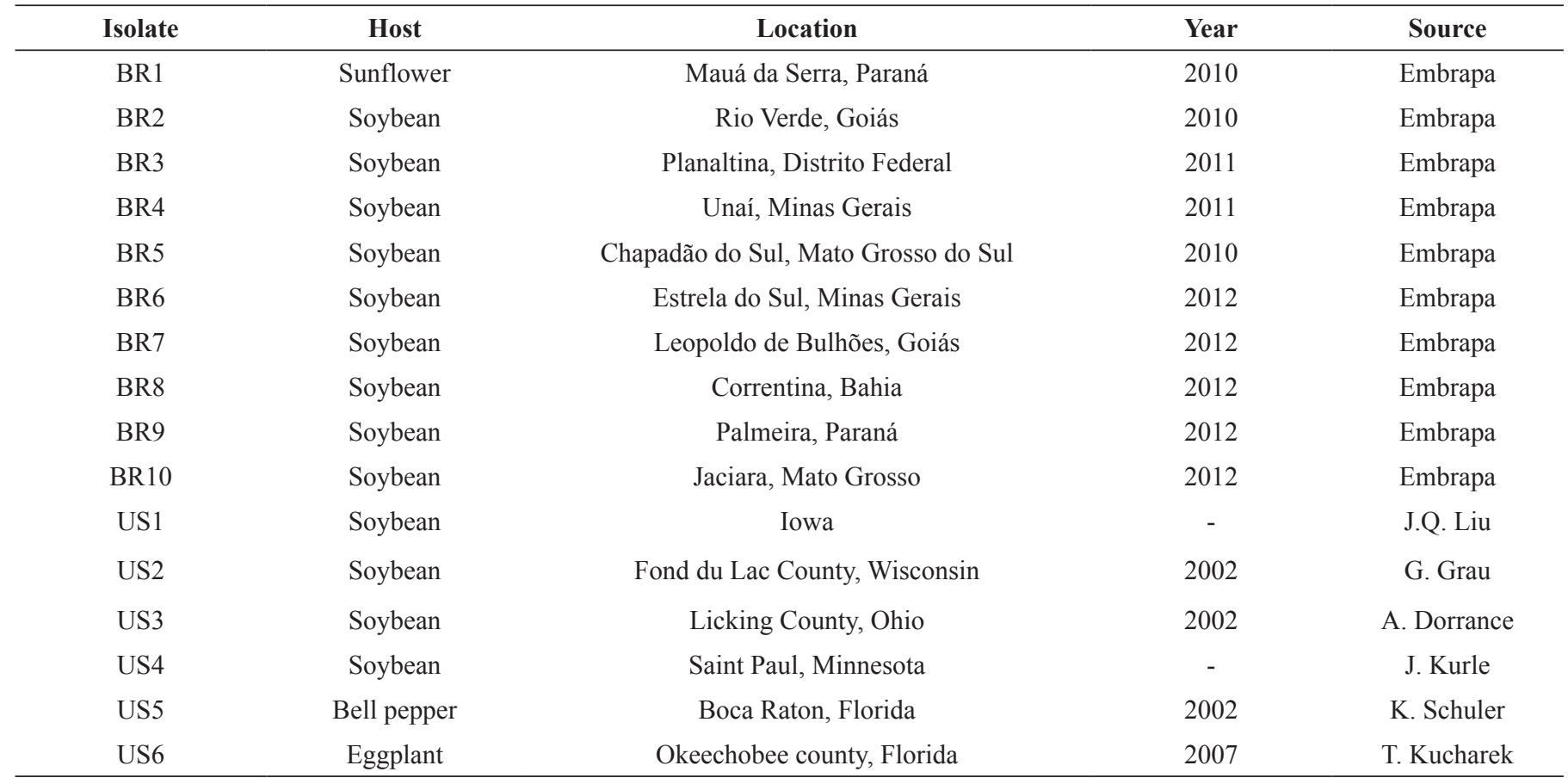


borer S. sclerotiorum mycelial plug from all isolates in this study. Petri plates were then placed inside zip lock bags and transferred to $20^{\circ} \mathrm{C}$ and $30^{\circ} \mathrm{C}$ tissue chambers under $12 / 12 \mathrm{~h}$ dark/light conditions. Leaflets were visually rated three days after inoculation, measuring pathogenicity (presence/absence) and severity (percentage of affected leaflet area). Each experiment was arranged in a factorial design with three replicates. The experiment was performed twice.

\section{Apothecial production}

To obtain sclerotia of uniform age and size, $6 \mathrm{~mm}$-diameter $S$. sclerotiorum mycelial plugs were cut with a cork borer from the leading edge grown on PDA from each isolate and seeded on soymilk medium (24) in 9-cm Petri plates. The plates were placed in tissue chambers at $20^{\circ} \mathrm{C}$, under $12 / 12 \mathrm{~h}$ dark/light conditions, for 14 days; then, they were placed open for 2 days in a laminar flow hood to air dry, so that sclerotia could be easily harvested. Five sclerotia of similar size, ranging from 3.0 to $4.0 \mathrm{~mm}$ long, from each isolate, were transferred to $10 \times 15 \mathrm{~cm}$ Petri plates containing fine autoclaved sand, distributed on $250 \mathrm{~g}$ sand with $100 \%$ moisture capacity. The plates were sealed with sticky tape and autoclaved water was added as needed. There were 12 Petri plates per isolate, which were used in two different experiments with six Petri plates each. In one experiment, three Petri plates were placed in chambers at $20^{\circ} \mathrm{C}$ and $30^{\circ} \mathrm{C}$, respectively, under $12 / 12 \mathrm{~h}$ dark/light conditions. In the other experiment, six Petri plates of each isolate were placed at $4^{\circ} \mathrm{C}$ for 40 days and then three Petri plates each were transferred to $20^{\circ} \mathrm{C}$ and $30^{\circ} \mathrm{C}$, respectively. Carpogenic germination of sclerotia was counted at every three days, after the first apothecia were formed, until 70 days after seeding in the first experiment and 70 days after removal from vernalization in the second experiment. Both experiments had three replicates (Petri plates) in a completely randomized design and were repeated twice. Isolates US5 and US6 were used only in the second repetition due to the time when isolates became available.

Data were analyzed for normality and independence of errors and common variances among treatments. Analysis of variance was combined over two runs of experiments arranged as 16 (isolates) $\mathrm{x}$ 2 (temperatures) random factorial design for mycelial growth and severity on bean, soybean and canola, separately according to $\mathrm{F}$ test in ANOVA. Differences among means above 1\% significance were separated according to Tukey's Honestly Significant Difference test $(P=0.05)$. Statistical analysis was performed with SAS 9.3 software (SAS Institute, Carry, NC, USA). The data for apothecial production were highly variable among replicates and repetitions, and means and standard errors were compared.

\section{RESULTS AND DISCUSSION}

\section{Mycelial growth}

Significant differences in mycelial growth were observed among isolates between $20^{\circ} \mathrm{C}$ and $27^{\circ} \mathrm{C}$, as well as temperature $\mathrm{x}$ isolate interaction (Table 2). Due to such interaction, isolates were analyzed within each temperature (Figure 1). All isolates grew faster at $20^{\circ} \mathrm{C}$ and differed significantly from the same set of isolates incubated at $27^{\circ} \mathrm{C}$. Mean colony growth was $6.2 \mathrm{~cm}$ and $4.3 \mathrm{~cm}$ at $20^{\circ} \mathrm{C}$ and $27^{\circ} \mathrm{C}$, respectively. At $20^{\circ} \mathrm{C}, \mathrm{US} 3$ and $\mathrm{BR} 2$ presented smaller colony diameter and differed from US6, which had the largest colony diameter, while the other 13 isolates did not differ from the smallest and the largest colony diameters measured at 36 hours after seeding on PDA Petri plates. At $27^{\circ} \mathrm{C}$, US6 presented the smallest colony diameter, opposite to its diameter at $20^{\circ} \mathrm{C}$. US1 differed from US6, BR2, BR5, BR10 and US3 but its growth was statistically similar to that of the other isolates at $27^{\circ} \mathrm{C}$.

Table 2. Analysis of variance for Sclerotina sclerotiorum colony growth diameter $(\varnothing \mathrm{cm})$ over two runs of experiments arranged in 16 (different isolates) $\mathrm{x} 2$ (temperatures) random factorial design measured 36 hours after $6 \mathrm{~mm}$ mycelial plugs were seeded in $9 \mathrm{~cm}$ Petri plates and incubated at $20^{\circ} \mathrm{C}$ and $27^{\circ} \mathrm{C}$.

\begin{tabular}{lccc}
\hline Source of variation & df & Mean square & F ratio \\
\hline Temperature & 1 & 235.43 & $* * *$
\end{tabular}

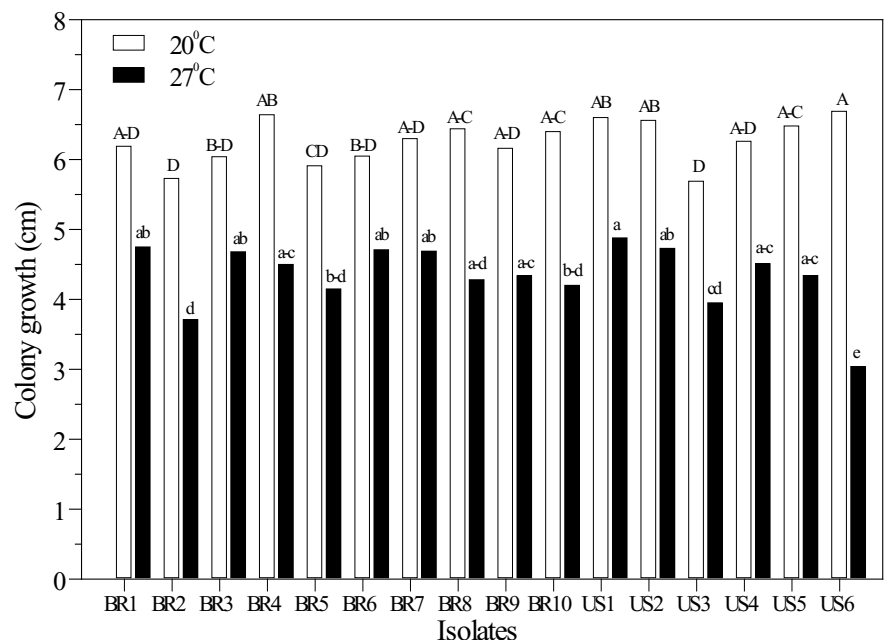

Figure 1. Sclerotinia sclerotiorum colony growth diameter $(\varnothing \mathrm{cm})$ for 16 different isolates measured 36 hours after $6 \mathrm{~mm}$ mycelial plugs were seeded in $9 \mathrm{~cm}$ Petri plates and incubated at $20^{\circ} \mathrm{C}$ and $27^{\circ} \mathrm{C}$. Means were separated according to Tukey's test $(P=0.01)$. Means followed by the same letter are not significantly different.

\begin{tabular}{lccc} 
Isolate & 15 & 1.40 & $* * *$ \\
Temperature x Isolate & 15 & 1.16 & $* * *$ \\
Error & 189 & 0.09 & - \\
\hline *** Significant differences at $P<0.001$ & &
\end{tabular}

*** Significant differences at $P<0.001$.

Pathogenicity and aggressiveness on bean, soybean and canola

All isolates were capable of causing necrosis on detached leaves of bean, soybean and canola at $20^{\circ} \mathrm{C}$ and $30^{\circ} \mathrm{C}$. Analyses were performed separately according to the host. Significant temperature $\mathrm{x}$ isolate interaction was observed for all evaluated hosts (Table 3). Regardless of the host and the isolate, disease severity in the detached leaf was higher at $20^{\circ} \mathrm{C}$ than at $30^{\circ} \mathrm{C}$ (Figure 2). At $20^{\circ} \mathrm{C}$, significant differences were observed among isolates for all hosts. For bean, isolates US5 and BR6 were more aggressive than isolates US6, BR1, US4, US3, BR4, BR5, BR7, US2 and BR9. For soybean, BR5, BR2 and BR6 were more aggressive than US4, US1, US6 and US5. For canola, the most aggressive isolates were US5, US6, BR4, BR8 and BR6, while the least aggressive isolates were US1, US3 and BR7. At $30^{\circ} \mathrm{C}$, there was no significant difference in disease severity among isolates inoculated on bean and soybean. Mean disease severity values were $1.8 \%$ and $3.1 \%$ for bean and soybean, respectively. For canola, at $30^{\circ} \mathrm{C}$, isolates US1 and US6 were less aggressive than isolates BR1, BR9 and BR3. 
Table 3 Analysis of variance for Sclerotina sclerotiorum disease severity combined over two runs of experiments arranged in 16 x 2 random factorial design for bean, soybean and canola.

\begin{tabular}{lccccccc}
\hline & \multicolumn{2}{c}{ Bean } & \multicolumn{2}{c}{ Soybean } & \multicolumn{2}{c}{ Canola } \\
\hline Source of variation & df & Mean square & F ratio & Mean square & F ratio & Mean square & F ratio \\
Temperature & 1 & 285932.1 & $* * *$ & 301653.5 & $* * *$ & 196821.4 & $* * *$ \\
Isolate & 15 & 372.6 & $* * *$ & 2536.4 & $* * *$ & 655.2 & $* * *$ \\
Temperature x Isolate & 15 & 316.3 & $* * *$ & 2517.8 & $* * *$ & 486.1 & -23.68 \\
Error & 189 & 68.4 & - & 6420 & - & - \\
\hline
\end{tabular}

*** Significant differences at $P<0.001$.

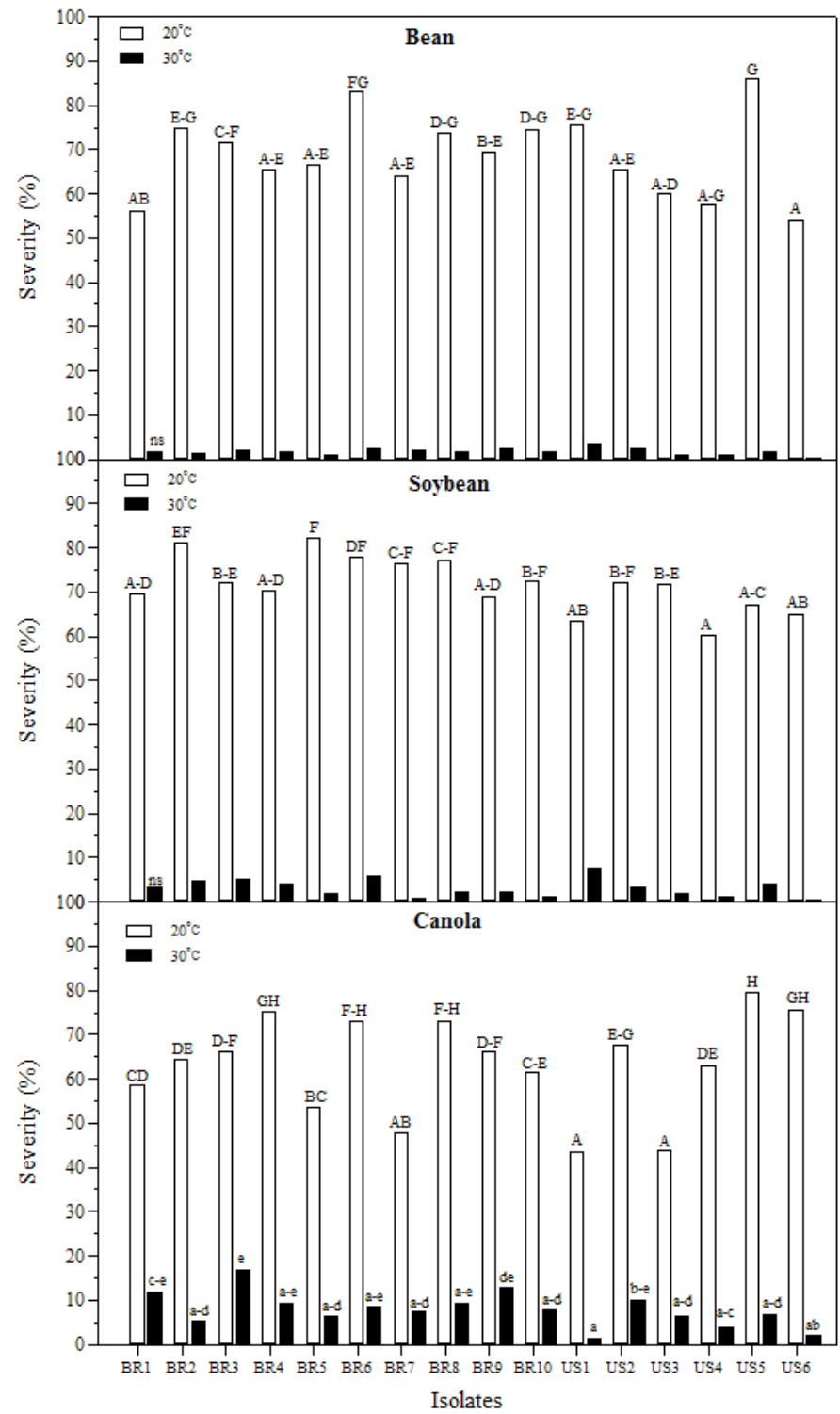

Figure 2. Percentage of leaf area covered with Sclerotinia sclerotiorum symptoms (severity) three days after inoculation ( $6 \mathrm{~cm}$ mycelia plug) with 16 different isolates on bean, soybean and canola. Means were separated according to Tukey's test $(P=0.01)$. Means followed by the same lowercase letter $\left(30^{\circ} \mathrm{C}\right)$ and capital letter $\left(20^{\circ} \mathrm{C}\right)$ for each host are not significantly different; $\mathrm{ns}=$ no significant differences among means in this column.

\section{Apothecial production}

None of the 16 isolates produced apothecia at $30^{\circ} \mathrm{C}$, regardless of preconditioning. At $20^{\circ} \mathrm{C}$, only isolates from Brazil germinated without preconditioning at $4^{\circ} \mathrm{C}$ for 40 days (Figure 3). Isolates BR1, $\mathrm{BR} 5$ and $\mathrm{BR} 9$ germinated only in the second repetition, whereas BR3 and BR7 did not germinate at all. At $20^{\circ} \mathrm{C}$, among Brazilian isolates that germinated, the first apothecia were observed from 31 to 67 days after seeding of sclerotia in sand without preconditioning. With preconditioning, all isolates from Brazil and the USA, except US3, germinated in the first repetition; isolates BR3, BR4, US2, US3, US5 and US6 did not germinate in the second repetition, and the first apothecia were observed from 7 to 56 days after sclerotia were seeded for all isolates.

Temperature exerts a significant effect on apothecial formation, ascospore germination and growth, as well as on initiation of infection and lesion expansion $(1,9)$. The favorable temperature for mycelial growth has been reported to range from $20^{\circ} \mathrm{C}$ to $25^{\circ} \mathrm{C}(1)$. In our study, all isolates grew faster at $20^{\circ} \mathrm{C}$ than at $27^{\circ} \mathrm{C}$, indicating that, regardless of the origin (tropical/subtropical to temperate), the fungus grows faster at lower temperatures.

Studies with dandelion, soybean and sunflower have shown that $S$. sclerotiorum isolates vary in aggressiveness $(6,12,13,14)$. Abawi \& Grogan (1) observed that detached bean leaves had similar lesion sizes when incubated at $20^{\circ} \mathrm{C}$ and $25^{\circ} \mathrm{C}$ but no lesion when incubated at $30^{\circ} \mathrm{C}$ or $5^{\circ} \mathrm{C}$ with a single isolate. In our study, lesions were produced at $30^{\circ} \mathrm{C}$, regardless of the host and the isolate, but the disease severity was higher at $20^{\circ} \mathrm{C}$ than at $30^{\circ} \mathrm{C}$. The isolates were more aggressive at the reported favorable temperature. Isolates from both Brazil and the USA were present among the most and the least aggressive isolates. Although Sclerotinia stem rot has been reported in the tropical region of Brazil causing epidemic outbreaks, it has been most frequent at altitudes above $700 \mathrm{~m}$, where the night temperature is lower during rainy seasons (8). Our results show no adaptation of isolates from tropical and subtropical regions to grow or infect at higher temperatures. At $30^{\circ} \mathrm{C}$, difference in aggressiveness among isolates was observed only for canola.

Apothecial production at $30^{\circ} \mathrm{C}$ was reported by Sun \& Yang (21) for sclerotia collected from a soybean field, although the number of germinated sclerotia showed a substantial decrease at $25^{\circ} \mathrm{C}$ and $30^{\circ} \mathrm{C}$ when compared with that at lower temperatures. Sun \& Yang (21) suggested that the production of apothecia at $30^{\circ} \mathrm{C}$ could be related to the geographical origins of the isolate and the possible adaptation of isolates to warmer temperatures, but this hypothesis was not confirmed in our study. Regardless of the origin, none of the 16 isolates produced apothecia at $30^{\circ} \mathrm{C}$, with or without preconditioning. Similarly, Wu \& Subbarao (23) did not observe carpogenic germination at a constant temperature of $25^{\circ} \mathrm{C}$ but noted that a 5-day period at $30^{\circ} \mathrm{C}$ for sclerotia 

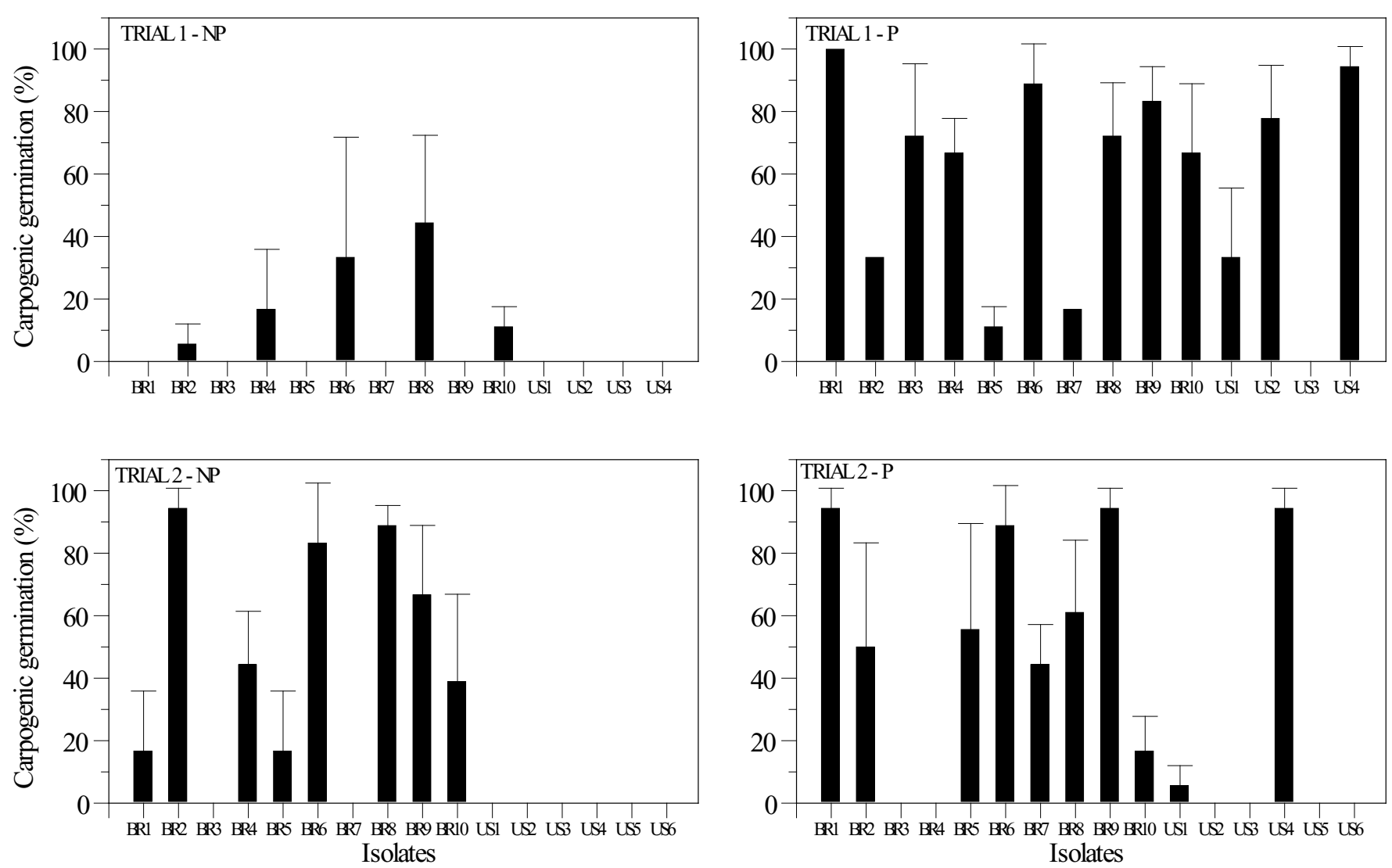

Figure 3. Means and standard error of carpogenic germination (\%) for Sclerotinia sclerotiorum isolates evaluated 70 days after incubation in growth chamber at $20^{\circ} \mathrm{C}, 12 / 12$ photoperiod, in two different trials (trial 1 and trial 2): with no preconditioning (NP) and preconditioned (P), at $4^{\circ} \mathrm{C}$, for 40 days.

incubated at $15^{\circ} \mathrm{C}$ did not affect carpogenic germination.

The capability of sclerotia to germinate carpogenically at $20^{\circ} \mathrm{C}$ differed among isolates, between replicates and between repetitions, regardless of the isolate's origin (Brazil or the USA). Dillard et al. (5) also observed variability in carpogenic germination between trial runs. The temperature at which sclerotia are produced affects the carpogenic germination, and germination varies among the geographic origins of isolates. Huang \& Kozub (9) observed that, for sclerotia produced at $10^{\circ} \mathrm{C}$, germination occurred readily for isolates from cold regions, while little or no germination occurred for isolates from warmer regions. Sclerotia formed at $25^{\circ} \mathrm{C}$ showed little or no germination unless they were preconditioned at $10^{\circ} \mathrm{C}$, but preconditioning was not effective for all isolates. In this study, the same temperature $\left(20^{\circ} \mathrm{C}\right)$ used for sclerotium production may have influenced the germination capacity without preconditioning. Only sclerotia from Brazilian isolates were capable of germinating carpogenically without preconditioning when produced at $20^{\circ} \mathrm{C}$. In tropical areas of Brazil, low temperatures, below $10^{\circ} \mathrm{C}$, do not occur between growing seasons. This environment could have selected ecotypes that are capable of germinating without preconditioning at low temperatures. Apothecial development from sclerotia collected in the field without preconditioning has been reported in Brazil (19).

Results did not indicate any adaptation of S. sclerotiorum isolates from Brazil to grow or colonize leaflets at higher temperatures, compared with isolates from the USA. However, sclerotia from S. sclerotiorum isolates from Brazil, but not from the USA, were capable of germinating carpogenically without preconditioning.

\section{ACKNOWLEDGEMENTS}

We would like to thank "Conselho Nacional de Desenvolvimento Científico e Tecnológico - CNPq", for the granted fellowship, and Dr. Maurício Meyer, for providing S. sclerotiorum isolates from the Brazilian Cerrado region.

\section{REFERENCES}

1. Abawi, G.S.; Grogan, R.G. Epidemiology of diseases caused by Sclerotinia sclerotiorum. Phytopahtology, St. Paul, v.69, n.8, p.899-904, 1979.

2. Abawi, G.S.; Grogan, R.G. Source of primary inoculum and effects of temperature and moistures on infection of beans by Whetzelinia sclerotiorum. Phytopathology, St. Paul, v.65, n.3, p.300-309, 1975.

3. Boland, G.J.; Hall, R. Index of plant hosts of Sclerotinia sclerotiorum. Canadian Journal of Plant Pathology, Ontario, v.16, n.2, p.93-108, 1994.

4. Buntin, D.; Grey, T.; Harris, G.H. Jr.; Phillips, D.; Buck, J.; Prostko, E.; Raymer, P.; Smith, N.; Sumner, P.; Woodruff, J. Canola production in Georgia. Univeristy of Georgia Extension Bulletin, Athens, n. 1331, p.1-25, 2013. Disponível em: <http://www.agecon.uga.edu/extension/pubs/documents/ CanolaProduction.pdf.> Acesso em: 14 abr. 2013.

5. Dillard, H.R.; Ludwig, J.W.; Huter, J.E. Conditioning scerotia of Sclerotinia sclerotiorum for carpogenic germination. Plant Disease, St. Paul, v.79, n.4, p.411-415, 1995.

6. Ekins, M.G.; Hayden, H.L.; Aitken, E.A.B.; Goulter, K.C. Population structure of Sclerotinia sclerotiorum on sunflower in Australia. Australasian Plant Pathology, Victoria, v.40, n.2, p.99-108, 2011

7. Farr, D.F.; Rossman, A.Y. Fungal Databases. Washington: Systematic Mycology and Microbiology Laboratory - USDA, 2016. Available: <http:// nt.ars-grin.gov/fungaldatabases/>. Accessed: 15 Feb. 2016. 
8. Görgen, C.; Hikishima, M.; Silveira Neto, A.; Carneiro, L.; Lobo Junior, M. Mofo-branco (Sclerotinia sclerotiorum). In: Almeida, A.M.R.; Seixas, C.D.S. Soja: doenças radiculares e de hastes e inter-relações com o manejo do solo e da cultura. Londrina: Embrapa Soja, 2010. p.73-104.

9. Huang, H.C.; Kozub, G.C. Temperature requirements for carpogenic germination of sclerotia of Sclerotinia sclerotiorum isolates of different geographic origin. Botanical Bulletin of Academia Sinica, Taipei, v.32, p.279-286, 1991.

10. Huang, H.C.; Kozub, G.C. Influence of inoculum production temperature on carpogenic germination of sclerotia of Sclerotinia sclerotiorum. Canadian Journal of Microbiology, Ottawa, v.39, p.548-550, 1993.

11. Huang, H.C.; Kozub, G.C. Germination of immature and mature sclerotia of Sclerotinia sclerotiorum. Botanical Bulletin of Academia Sinica, Taipei, v.35, p.243-247, 1994.

12. Koga, L.J.; Bowen, C.R.; Godoy, C.V.; Oliveira, M.C.N.; Hartman, G.L. Mycelial compatibility and aggressiveness of Sclerotinia sclerotiorum isolates from Brazil and the United States. Pesquisa Agropecuária Brasileira, Brasília, DF, v.49, n.4, p.265-272, 2014.

13. Kull, L.; Pedersen, W.; Palmquist, D.; Hartman, G.L. Mycelial compatibility grouping and aggressiveness of Sclerotinia sclerotiorum. Plant Disease, St. Paul, v.88, n.4, p.325-332, 2004.

14. Marciano, P.; Di Lenna, P.; Magro, P. Oxalic acid, cell wall-degrading enzymes and $\mathrm{pH}$ in pathogenesis and their significance in the virulence of two Sclerotinia sclerotiorum isolates on sunflower. Physiological Plant Pathology, London, v.22, n.3, p.339-345, 1983.

15. Mila, A.L.; Yang, X.B. Effects of fluctuating soil temperature and water potential on sclerotia germination and apothecial production of Sclerotinia sclerotiorum. Plant Disease, St. Paul, v.92, n.1, p.78-82, 2008

16. Phillips, A.J.L. Carpogenic germination of sclerotia of Sclerotinia sclerotiorum: a review. Phytophylactica, Pretoria, v.19, n.4, p.279-283, 1987.

17. Pratt, R.G.; Rowe, D.E. Comparative pathogenicity of isolates of Sclerotinia trifoliorum and S. sclerotiorum on alfalfa cultivars. Plant Disease, St. Paul, v.79, n.5, p.474-477, 1995.

18. Purdy, L.H. Sclerotinia sclerotiorum: History, diseases and symptomatology, host range, geographic distribution, and impact. Phytopathology, St. Paul, v.69, n.8, p.875-880, 1979.

19. Reis, E.M.; Casa, R.T.; Gava, F.; Moreira, E.N.; Sachs, C. Indução da germinação carpogênica de escleródios de Sclerotinia sclerotiorum sob diferentes substratos. Revista de Ciências Agroveterinárias, Lages, v.10, n.2, p.145-150, 2011.

20. Steadman, J.R. White mold - a serious yield-limiting disease of bean. Plant Disease, St. Paul, v.67, n.4, p.346-350, 1983.

21. Sun, P.; Yang, X.B. Light temperature, and moisture effects on apothecium production of Sclerotinia sclerotiorum. Plant disease, St. Paul, v.84, n.12, p.1287-1293, 2000.

22. Turrill, W.B. The ecotype concept. A consideration with appreciation and criticism, especially of recent trends. New Phytologist, Cambridge, v.45, n.1, p.34-43, 1946

23. Wu, B.M.; Subbarao, K.V. Effects of soil temperature, moisture, and burial depths on carpogenic germination of Sclerotinia sclerotiorum and S. minor. Phytopathology, St. Paul, v.98, n.10, p.1144-1152, 2008.

24. Xiang, Y.; Herman, T.; Hartman, G.L. Utilizing soybean milk to culture soybean pathogens. Advances in Microbiology, London, v.4, n.2, p.126132, 2014 